\title{
Kent and Oakley: A Re-Examination of the Common Law Duty to Give Reasons for Grants of Planning Permission and Beyond
}

\section{Joanna Bell*}

St John's College, University of Cambridge

1. The Court of Appeal has recently been faced with two important cases which share a similar fact pattern. In both $R$ (Campaign to Protect Rural England, Kent) v Dover DC [2016] EWCA Civ 936 and Oakley v South Cambridgeshire DC [2017] EWCA Civ 71 the applicant sought judicial review in order to argue that a local planning authority, in granting planning permission for the development of land, was under and had failed to fulfil a legal duty to provide adequate reasons. In both cases, the Court of Appeal accepted the applicant's argument, concluding that the local planning authorities, in failing to provide legally adequate reasons, had acted unlawfully. ${ }^{1}$

2. This article has two main aims. The first is to set out the facts and the judgments of the Court of Appeal in both Kent and Oakley in some detail. The second is then to explore the Court of Appeal's reasoning in these cases against the backdrop of three important questions.

3. The first question against which Kent and Oakley fall to be considered is the relatively specific one of when a local planning authority is placed under a common law duty to offer reasons for grants of planning permission. Recent legislative change in this area has meant that this question has gained renewed practical importance. While the Court of Appeal in Kent and Oakley was hesitant to embrace a general common law duty to give reasons in relation to all grants of planning permission it did recognise that there are circumstances in which such a duty will arise. In particular, the Court of Appeal in both Kent and Oakley were of the view that there are certain 'protected public interests' 2 which, if at stake, are sufficient to trigger a duty to provide reasons. Important questions arise, however, as to precisely how the Court of Appeals' reasoning in these cases ought to be understood and thus how far this line of reasoning could be extrapolated in future planning cases.

\footnotetext{
*With many thanks to Professor Liz Fisher for her helpful comments and reflections. Any errors or omissions are my own.

${ }^{1}$ The Court of Appeal in $R$ (Campaign to Protect Rural England, Kent) v Dover DC [2016] EWCA Civ 936, Official Transcript quashing the grant of planning permission ([23]) and in Oakley $v$ South Cambridgeshire DC [2017] EWCA Civ 71, Official Transcript inviting further submissions on the issue of remedy ([66]).

${ }^{2}$ See paragraph 7 of the article below on the sense in which I use this phrase.
} 
4. The second question against which these cases will be considered is that of what the Court of Appeal's reasoning, taken with other cases, show about the level of detail in which local planning authorities must present their reasons in cases where they grant permission for the development of land. Taken collectively, these cases indicate that it is important to distinguish between broadly two types of case. First, cases in which certain protected public interests are at stake. Here the local planning authority is placed under a duty to provide 'substantial reasons, ${ }^{3}$ detailing why it considers it justifiable to permit development in the face of the relevant interest. Second, 'ordinary' cases in which no protected public interest is at stake. Here the usual process of publishing reports and meeting minutes will be sufficient for the local planning authority to act lawfully.

5. The third question against which the Court of Appeal's reasoning in Kent and Oakley will be explored is the wider question of when administrative decision-makers more broadly will be placed under a common law duty to give reasons. Traditionally, the courts have tended to ground the common law duty to give reasons in a concern to protect individual dignity. The result of this is that the duty has tended to be confined to cases where a particularised decision is being taken about how some individual will be treated and where that decision will have a substantial impact on an important individual interest. Commentators, have long been urging the courts to embrace a very different understanding of the duty, grounded in more publicorientated normative concerns such as self-discipline and good administration, with the result that the duty to provide reasons would apply generally. The Court of Appeal in Kent and Oakley continued to resist this rather dramatic shift in thinking, embracing instead a midway position. According to this position, it is important to recognise that the duty to give reasons is not grounded in only one set of normative concerns. Thus while there are instances where a concern to protect individual dignity will justify recognition of a duty to give reasons, other important, but more public-orientated, interests may equally trigger this duty.

6. Before turning to the facts and judgments in Kent and Oakley it is helpful to add three further points. Firstly, it is helpful to say something on two matters of language. I refer throughout this article to 'the common law duty to give reasons.' This choice of phrase, however, ought not to be thought of as denoting the idea that there is some singular vision of reason-giving which underlies all of the case law on this subject. Indeed, in a sense, what this article seeks to show is that the Court of Appeal is moving in the opposite direction: towards a pluralistic understanding of the common law which sees reason-giving as being grounded in an array of normative concerns. Something ought also to be said on what this article means by saying that the Court of Appeal in Kent and Oakley intervened to protect a 'protected public interest.' As will be explained below, there is an important ambiguity inherent in the Court of Appeal's reasoning in these two cases about precisely what it was about the relevant public interests which triggered the duty to give reasons. 'Protected public interest', where it appears in this article, accordingly ought to be read loosely.

$3 \quad \operatorname{Kent}(\mathrm{n} 1),[21]$. 
7. Second, something should also be said about the legislative background to Kent and Oakley. In determining a planning application, a planning authority will reach one of broadly two conclusions. On the one hand, the planning authority may resolve to refuse planning permission. Where this is the case, legislation has long provided ${ }^{4}$ that the authority is under a statutory duty to explain its reasons to the disappointed applicant. This statutory duty is currently contained in article 35 of the Town and Country Planning (Development Management Procedure) (England) $2015^{5}$ which provides that 'where planning permission is refused, the notice must state clearly and precisely their full reasons for the refusal, specifying all policies and proposals in the development plan which are relevant to the decision.' On the other hand, however, the planning authority may decide to grant planning permission. Legislation has not consistently provided for a statutory duty to give reasons in relation to such decisions. Such a statutory duty was introduced for the first time in $2003 .{ }^{6}$ It was, however, removed again in $2013 .{ }^{7}$ It is against the background of this legislative change that Kent and Oakley, in both of which the challenge was to a grant of planning permission, fall to be considered.

8. Third and finally, it ought also to be noted that the Supreme Court has recently granted permission to appeal to the local planning authority in Kent. ${ }^{8}$ The terms of this permission indicate that the court wishes to consider broadly 'the source, nature and extent of a local planning authority's duty to give reasons for a grant of planning permission. ${ }^{9}$ Far from rendering the discussion in this article unimportant, this pending appeal makes it all the more important to look closely at the Court of Appeal's reasoning in both Kent and Oakley. It will be of the utmost importance for the Supreme Court, in resolving this appeal, to have a clear understanding of the precise position which the Court of Appeal is in the process of carving out, of the implications of this position and of the further questions to which it gives rise.

\section{Kent}

9. At this stage it is helpful to introduce the facts and judgments of the Court of Appeal in Kent and Oakley. Kent concerned a decision to grant planning permission for the building by a company known as China Gateway International Ltd (CGI) of an extensive residential housing development across two sites in Kent. ${ }^{10}$ Importantly, one of the sites was located within the

\footnotetext{
${ }^{4}$ See especially Town and Country Planning (General Development Procedure) Order 1995 (SI 1995/419), article 22 (since repealed by Town and Country Planning (Development Management Procedure) (England) Order 2010 (SI 2010/2184).

${ }^{5}$ Town and Country Planning (Development Management Procedure) (England) 2015 (SI 2015/595). See also South Buckinghamshire DC v Porter (No 2) [2004] UKHL 33, [2004] 1 WLR 1953, [36] on the adequacy of standard of reason-giving which has tended to be required in planning cases.

${ }^{6}$ Town \& Country Planning (General Development Procedure) (England) (Amendment) Order 2003 (SI 2003/2047), article 5 .

7 Town \& Country Planning (Development Management Procedure) (England) (Amendment) Order 2013 (SI 2013/1238), article 7.

${ }^{8}$ http://www.landmarkchambers.co.uk/news.aspx?id=4730 (last accessed 22 April 2017).

${ }^{9}$ Ibid.

${ }^{10} \operatorname{Kent}(\mathrm{n} 1),[2]$.
} 
Kent Downs, a designated Area of Outstanding Natural Beauty. ${ }^{11}$ According to central government planning policy, ${ }^{12}$ in determining planning applications, local authorities are required to give 'great weight... to conserving landscape and scenic beauty' 13 in Areas of Outstanding Natural Beauty with the result that 'planning permission should be refused for major developments... except in exceptional circumstances. ${ }^{14}$ Relying on this policy, the initial recommendation of the planning officers was that CGI's proposal ought to be rejected. ${ }^{15}$ Instead, the planning officers recommended that the council look closely at an alternative proposal which had been identified by a consulted expert. ${ }^{16}$ The Planning Committee, however, rejected the planning officers' recommendations. ${ }^{17}$ The reasons offered by the Planning Committee did not explain in detail why it had decided to reject the planning officer's arguments and why it had deemed the proposed alternative unsuitable.

10. The applicant, a non-governmental organisation whose stated aims are to 'ensure that the countryside is protected for now and for future generations, ${ }^{18}$ sought to argue that the planning authority had failed to provide adequate reasons for its decision. Broadly two main issue arose for resolution. First, was the local authority under a legal duty to provide reasons for its decision? Second, if so, were the reasons given in the case adequate?

11. In relation to the first question, the Court of Appeal's answer was that the local planning authority was under a legal duty to give reasons for its decision and that this was so for two reasons. First, this was a case in which regulation 24 of the Environmental Impact Assessment Regulations $2011^{19}$ was engaged. This regulation places local planning authorities under a duty, in dealing with 'EIA applications, ${ }^{20}$ to 'make available for inspection... a statement containing... the main reasons and considerations on which the decision is based.' ${ }^{21}$ The local authority was accordingly under a statutory duty to make its reasons for granting planning

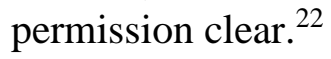

11 Ibid.

12 'National Planning Policy Framework' (Department for Communities and Local Government, March 2012) (NPPF).

${ }^{13}$ Ibid [115], cited at Kent (n 1), [6].

${ }^{14}$ Ibid, [116], cited at Kent (n 1), [6].

${ }^{15} \operatorname{Kent}(\mathrm{n} 1),[9]$.

16 Ibid, [9].

${ }^{17}$ Ibid, [14]-[15].

18 http://www.cpre.org.uk/what-we-do (last accessed 19th April 2017).

19 Town and Country Planning (Environmental Impact Assessment) Regulations 2011 (SI 2011/1824), regulation 24(1). (These regulations implement Council Directive 85/337/EEC of 27 June 1985 on the assessment of the effects of certain public and private projects on the environment as amended by Council Directive 97/11/EC of 3 March 1997 amending Directive 85/337/EEC on the assessment of the effects of certain public and private projects on the environment.)

${ }^{20}$ Defined in ibid, Schedules 1-2.

${ }^{21}$ Ibid, regulation $24(1)(\mathrm{c})$.

22 Note that at Kent (n 1), [23] Laws LJ appears to suggest that the proper remedial consequence of a finding of a breach of Regulation 24 is a quashing order. Doubts, however, have been raised as to the correctness of this conclusion by James Maurici QC who points out that it is difficult to reconcile with the conclusion of the Court of Appeal in $R$ (Richardson v North Yorkshire CC [2004] 1 WLR 1920 (CA) that breach of regulation 21(2) of the Town and Country Planning (Environmental Impact Assessment) (England and Wales) Regulations 1999 (SI 1999/293) (the statutory predecessor of regulation 24) will ordinarily result in a mandatory order (see: 
12. Second, this was also a case in which the common law itself imposed a duty to give reasons. The key factor here was the national planning policy. ${ }^{23}$ This policy made clear that the greatest of weight was to be accorded to the need to preserve Areas of Outstanding Natural Beauty in the making of planning decisions. The 'pressing nature of th[is] policy' ${ }^{24}$ in turn meant that:

A local planning authority which is going to authorise a development which will inflict substantial harm on an Area of Outstanding Natural Beauty must surely give substantial reasons for doing so. ${ }^{25}$

13. Given this conclusion, the second question then arose as to whether the reasons offered by the local planning authority in Kent were adequate. On this question, the Court of Appeal opined that the Planning Committee's departure from the clear recommendations of the planning officer, and failure to engage closely with the detail of these recommendations, meant that there was a considerable amount of ambiguity as to how precisely the committee had reached its decision. It was, in particular, impossible to know whether the committee had accepted or rejected the officer's assessment of the harm ${ }^{26}$ and its precise reasons for preferring CGI's original proposal over than identified in the report. ${ }^{27}$ This, the Court of Appeal suggested, was not acceptable: 'where the planning committee is disposed to disagree with the Council's officers - especially in an Area of Outstanding Natural Beauty case - it must engage with the officers' reasoning. ${ }^{28}$

\section{Accordingly, the Court of Appeal concluded:}

The Committee failed to give legally adequate reasons for their decision to grant planning permission. A statutory statement of reasons made under the EIA Regulations would have

\footnotetext{
http://www.landmarkchambers.co.uk/userfiles/documents/resources/CPRE\%20Kent\%20v\%20Dover\%20and\%20the \%20duty\%20to\%20give\%20reasons\%20-\%20James\%20Maurici\%20QC\%20.pdf (last accessed 13 May 2017). More broadly, Laws LJ's conclusion also seems to run counter to the general insistence on the part of the Supreme Court that domestic courts retain remedial discretion on finding a breach of European Union law generally (see especially Walton v Scottish Ministers [2012] UKSC 44, [2013] PTSR 51) and the EIA regime in particular (see especially $R$ (Champion) v North Norfolk DC [2015] UKSC 52, [2015] 1 WLR 3710; Ned Westaway, $R$ (Champion) v North Norfolk DC (2016) 28(3) JEL 523).

23 Note that James Maurici QC has characterised Kent as a case in which the court was concerned only with determining the content of the statutory duty (see link at (n 21)). On my reading, however, Laws LJ clearly also regarded this as a case in which a common law duty to give reasons arose. See especially Kent (n 1) at [14] (counsel said to place on 'oblique reliance' on regulation 24), [21]-[22] (the existence of regulation 24 of the EIA regulations mentioned as the third reason for recognising a duty to give reasons) and [31] (regulation 24 and NPPF spoken of as alternative bases for the duty to provide reasons).

${ }^{24}$ Kent (n 1), [21].

${ }^{25}$ Ibid.

${ }^{26}$ Ibid, [29].

${ }^{27}$ Ibid, [26].

${ }^{28}$ Ibid, [22].
} 
been required to grapple with the issue of harm much more closely than what the minutes disclose; and the stricture of the [central government planning policy] demand no less. ${ }^{29}$

\section{Oakley}

15. Oakley concerned a decision to grant permission for the building of a football stadium by Cambridge City Football Club. The site identified was located on designated Green Belt land. Like Areas of Outstanding Natural Beauty, central government planning policy provides for special protection of Green Belt land in the course of local planning decision-making. National policy, in particular, provides that 'inappropriate development is, by definition, harmful to the Green Belt and should not be approved except in very special circumstances. ${ }^{30}$ The Football Club's proposals were also inconsistent with the local authority's Local Development Plan. As in Kent, the planning officer in light of these policy considerations recommended that the Football Club's proposed development be rejected. ${ }^{31}$ The Planning Committee, however, rejected this conclusion opting to grant planning permission. ${ }^{32}$ No reasons, beyond a rather sparse report of the Council's discussion which was available in the minutes, were offered for this decision. ${ }^{33}$

16. The applicant, a local resident, initiated judicial review proceedings in order to challenge the planning authority's failure to supply reasons. Again, two broad questions arose for resolution here. First, was the local planning authority was under a duty to provide reasons for its decision? Second, if so, with what precisely was the authority required to engage in order for its reasons to be adequate?

17. In relation to the first question, the applicant advanced both a 'wide' and a 'narrow' argument. The wide argument ran as follows: ${ }^{34}$ local planning authorities, in opting to grant planning permission, are under a general legal duty to ensure that their reasons for deciding to do so are clear and accessible. This will not always require Planning Committees to compile a special document detailing their reasons. Where, for example, a Planning Committee elects to implement the recommendations of a Planning Officer, interested parties will be able to glean from the officer's report a clear understanding of the reasoning which led to the final decision. ${ }^{35}$

${ }^{29} \operatorname{Kent}$ (n 1), [31] (my emphasis).

${ }^{30}$ NPPF (n 6), [87], cited in Oakley (n 1), [4].

${ }^{31}$ Oakley (n 1), [6]-[9].

${ }^{32}$ Ibid, [10]-[12].

33 Ibid.

34 Ibid

35 Note one possible difficulty with this line of thinking is that the general way of thinking about the purpose of planning officer reports is that they are intended to 'inform the members of the relevant considerations relating to the application' ( $R v$ Mendip DC, ex parte Fabre (2000) 80 P CR 500 (QB), 509) rather than to set out the reasons for a decision to the public. Such reports as such are taken as being 'address to a knowledgeable readership including council members who, by virtue of that membership, may be expected to have a substantial local and background knowledge' ( $R$ (Nicholson v Allerdale BC [2015] EWHC 2510 (Admin), Official Transcript) as well as the background statutory and policy scheme ( $R$ v Selby DC, ex parte Oxton Farms [1997] EG 60 (CA). There appears to be something of a tension with this idea and the suggestion that the planning officer's report will often be sufficient to discharge the planning authority's duty to make its reasons clear to the public. 
In other contexts, however, it will be necessary for local planning authorities to specifically publish their reasons for a grant of permission. This is especially so where the committee departs from the recommendation of a Planning Officer. In such circumstances, the committee may need to explain clearly the nature of its disagreement with the content of the officer's report unless the nature of that disagreement is obvious.

18. The Court of Appeal in Oakley rejected the wide argument as the basis of its decision, albeit in different ways. Elias LJ expressed himself to be 'attracted ${ }^{36}$ to the argument but preferred to base his decision on the applicant's narrow contention. ${ }^{37}$ Sales LJ explicitly disagreed with the argument. ${ }^{38}$ Patten LJ simply expressed agreement with the court's conclusion. ${ }^{39}$ The article will return to the reasons for which the court rejected the applicant's wide argument shortly.

19. The applicant's narrower argument was to the effect that, regardless of whether a general duty to give reasons arose in relation to grants of planning permission, such a duty arose on the particular facts of Oakley. The Court of Appeal unanimously accepted this argument. The basis of the court's recognition of this duty was the fact that the grant of planning permission, in this instance, would involve the doing of damage to Green Belt land and was contrary to the area's Local Development Plan. Elias LJ thus opined that:

The decision in this case involved a development on the Green Belt and was also in breach of the development plan. Public policy requires strong countervailing benefits before such a development can be allowed, and affected members of the public should be told why the committee considers the development to be justified notwithstanding its adverse effect on the countryside... these considerations demand that reasons should be given. ${ }^{40}$

20. In a similar way, Sales LJ said as follows:

The foundation for the identification of a duty to give reasons for the decision of the Council in this case is the fact that the decision to grant planning permission appeared to contradict the local development plan and appeared to subvert the usual pressing policy concern that the Green Belt be protected (I think either of these factors alone would be sufficient) which engaged a particular onus of justification on the part of the Council. ${ }^{41}$

21. In light of this conclusion, the second question then arose: with what was the local planning authority required to engage in order to provide legally adequate reasons? In relation to this question, both judges thought it important that the local planning authority explain clearly and precisely its reasons for departing from the recommendations of the Planning Officer. The

\footnotetext{
${ }^{36}$ Oakley (n 1), [55].

${ }^{37}$ Ibid.

${ }^{38}$ Ibid, [73].

${ }^{39}$ Ibid, [68].

${ }^{40}$ Ibid, [60].

${ }^{41}$ Ibid, [80].
} 
reasons for which the judges thought this to be important were subtly different. For Sales LJ it was because departure without close engagement makes it difficult for interested parties to understand precisely how a conclusion was reached. ${ }^{42}$ For Elias LJ:

The significance of that fact is not simply that it will often leave the reasoning obscure. In addition, the fact that the committee is agreeing with a careful and clear recommendation from a highly experienced officer on a matter of such potential significance to very many people suggests that some explanation is required. ${ }^{43}$

\section{Question 1: When is there a Common Law Duty to Give Reasons for Grants of Planning Permission?}

22. With this overview of the Court of Appeal's decisions in Kent and Oakley in mind, this article can now turn to its second aim: considering the importance of the Court of Appeal's reasoning against the backdrop of three important questions. The first of these is the relatively specific question of when a local planning authority will be regarded as being under a common law duty to give reasons in relation to grants of planning permission. As noted in the introduction, it will important for the Supreme Court in resolving the Kent appeal to have a clear understanding of the position the Court of Appeal is beginning to carve out in relation to this question.

23. Before considering the light which Kent and Oakley shed on this question, it ought to be noted that it is a question which has gained renewed practical significance in recent years. The reason for this, as explained in the introduction, is that Kent and Oakley arise against the background of recent legislative change. Regulations enacted in $2013,{ }^{44}$ in particular, served to remove a general statutory duty to give reasons for grants of planning permission which had existed in law for a period of ten years. This has meant that, while the question of whether a common law duty to give reasons has remained dormant for a decade (given that interested parties wishing to obtain reasons have been able to rely on the statutory duty) the question of the extent to which it available to plug the gap left by this legislative change has become of the upmost practical importance.

\section{No General Duty?}

24. What position, then, has the Court of Appeal taken in Kent and Oakley on the question of when a common law duty to give reasons for grants of planning permission will arise? The first point to note is that the Court of Appeal in both cases was hesitant to embrace a very broad common law duty to give reasons in this context. Laws LJ in Kent, for instance, was careful to emphasise that he regarded Kent as an 'unusual case' 45 which ought not to be read as 'imposing in general

\footnotetext{
${ }^{42}$ Ibid.

${ }^{43}$ Ibid, [61].

${ }^{44}$ (n 6).

${ }^{45} \operatorname{Kent}(\mathrm{n} 1),[32]$.
} 
an onerous duty on local planning authorities to give reasons for the grant of permissions. 46 Similarly, both judges in Oakley rejected the applicant's 'wider' argument to the effect that local planning authorities are under a general duty to make their reasons clear and accessible, albeit Sales LJ more strongly than Elias LJ.

25. The Court of Appeal's reticence in this regard was quite understandably motivated by three main considerations. First, the recognition of such a general duty would involve a considerable departure from the existing case law on this subject. This is true both of the pre-2003 and post2013 case law. In $R v$ Aylesbury Vale DC ex parte Chaplin (1998) 76 P \& CR 207, for instance, the Court of Appeal explicitly rejected the suggestion that local planning authorities are under a general duty to provide reasons for grants of planning permission. ${ }^{47}$ More recently, Lang $\mathrm{J}$ in $R$ (Hawksworth Securities Plc) v Peterborough CC [2016] EWHC 1870 (Admin) ${ }^{48}$, rejected an argument to the effect that the local planning authority was dutybound to make clear its reasons for authorising the building of a shopping facility despite a commitment to promoting a similar facility in another part of the city.

26. Second, the Court of Appeal was concerned both that imposition of a general common law duty to ensure that reasons for grants of planning permission are clear and accessible may place local planning authorities under a considerable administrative burden and that the courts are particularly ill-placed to assess the full extent of that burden. Laws LJ in Kent for instance emphasised that there is a 'clear public interest in the expeditious resolution of planning issues ${ }^{49}$ which militates against imposition of such a general duty, even in cases where no fundamental interest is at stake. Similarly, Sales LJ in Oakley stressed that matters such as delay and administrative impact are 'difficult for a court to assess ${ }^{, 50}$ and accordingly that 'the court should be wary of stepping in to impose a general duty. ${ }^{, 51}$

27. Third, and relatedly, the Court of Appeal was especially reluctant to impose a general common law duty to give reasons in circumstances where the political branches of government have recently chosen to remove a general statutory duty of a similar effect. Sales LJ in particular ${ }^{52}$ was concerned that to replicate in common law something akin to a statutory duty which government had recently chosen to remove would overstep the mark and amount to the usurpation of a function better performed by political actors.

\section{An Exception: Protected Public Interests?}

28. That said, the Court of Appeal in both Kent and Oakley clearly recognised that there are circumstances in which these various considerations can be overridden. In particular, what

\footnotetext{
${ }^{46}$ Ibid.

${ }^{47}$ See also $R v$ Poole BC, ex parte Beebee [1991] 2 PLR 27; $R v$ Mendip DC (2000) 80 P \& C R 500.

${ }^{48} R$ (Hawksworth Securities Plc) v Peterborough CC [2016] EWHC 1870 (Admin), Official Transcript.

${ }^{49} \operatorname{Kent}(\mathrm{n} 1),[20]$.

${ }^{50}$ Oakley (n 1), [76].

${ }^{51}$ Ibid.

${ }^{52}$ Ibid.
} 
emerges from the reasoning in these cases is the idea that there are certain protected interests in relation to which a common law duty to give reasons will arise. Collectively, Kent and Oakley suggest that at least three such public interests fall into this category: the preservation of Areas of Outstanding Natural Beauty, the preservation of Green Belt land and the consistent application of Local Development Plans.

29. The basic normative idea is simple: although the Court of Appeal recognises that there are important considerations militating against recognition of a general duty to give reasons for grants of planning permission, these considerations are outweighed when certain protected public interests are at stake. Here, the importance of preserving the relevant interest justifies placing 'a particular onus of justification' ${ }^{53}$ on the local planning authority. There are a number of reasons for doing so. One is that placing the planning authority under a duty to explain in detail its reasons for authorising permission to inflict harm on the relevant aspect of the environment will ensure that the authority turns its mind to all of the relevant dimensions of the issue and ensure that its reasons for authorising the harm are very good ones. Another is that 'affected members of the public should be told why the committee considers the development to be justified notwithstanding its adverse effect on ${ }^{54}$ the relevant public interest. This will be important in order that any unlawfulness in the planning authority's reasoning process can be easily identified and that the decision can be properly tested in the political sphere.

30. There is, however, an ambiguity in the Court of Appeal's reasoning in Kent and Oakley which ought to be noted. The ambiguity concerns precisely what it is about certain public interests which trigger a common law duty to provide reasons. The Court of Appeal's reasoning suggests two possible ways of thinking. According to the first, which plays a considerable role in Laws LJ's reasoning in Kent, a particular public interest will trigger a common law duty to give reasons when central government planning policy clearly designates that interest as being of high priority. Under this approach, the recognition of a duty to give reasons is grounded in a concern to ensure that local planning authorities take seriously the planning priorities of central government. Thus the main reason for which a duty to give clear reasons was thought to arise in Kent was that central government policy clearly marked out the preservation of Areas of Outstanding Natural Beauty as being a matter of great weight. ${ }^{55}$ According to the second, which plays a greater role in the Court of Appeal's reasoning in Oakley, certain public interests will trigger a common law duty to give reasons of themselves, merely because they are matters in which the public has a fundamental interest. Thus, for Elias LJ the public has 'a strong and continuing interest... in the character of the environment in which they live ${ }^{56}$ and these 'nonpecuniary interests ${ }^{, 57}$ alone provide 'powerful reasons for imposing a duty to give reasons. ${ }^{58}$

\footnotetext{
${ }^{53}$ Ibid, [80].

${ }^{54}$ Ibid, [60].

${ }^{55}$ See especially Kent (n 1), [31]: 'the strictures of the NPPF demand no less.'

${ }^{56}$ Oakley (n 1), [59].

${ }^{57}$ Ibid.

${ }^{58}$ Ibid.
} 
31. These differences in thinking are of both academic and practical interest. On an academic level, it may be said that they reflect different normative understandings of the separation of powers and its relationship with protection of public interest. According to the first, protection of the public's interests lies primarily within the purview of the political branches of government. It is accordingly the task of central government to identify those interests of the public which are deserving of special protection. The task of the court is the lesser of one of ensuring that those policy choices are taken seriously, and applied consistently, across all levels of government. According to the second, the courts have a greater legitimate role in identifying and protecting certain interests in which the public as a whole has an interest. They may, accordingly, develop the common law, including the duty to give reasons, so as to provide legal protection for these interests and to impose high standards on administrative bodies considering inflicting harm on them.

32. On a practical level, there may be future cases (if the Supreme Court upholds the general thrust of the Court of Appeal's approach) where the resolution of this ambiguity one way rather than the other makes a practical difference. This is especially so given that Brexit and Great Repeal Bill bring with them the very real possibility that aspects of the environment which are currently accorded a very considerable degree of weight in national planning policy and law, as a necessary corollary of EU membership, may in the future be accorded less weight.

33. Take, for instance, the Air Quality Directive ${ }^{59}$ in relation to which the UK government has, in recent years, been the subject of lengthy and widely reported litigation. ${ }^{60}$ This Directive, among other things, affirms an obligation on the part of member states of the European Union to reduce levels of nitrogen dioxide present in ambient air below specified levels. By necessity, this aim is currently accorded high priority in both national planning policy ${ }^{61}$ and law. ${ }^{62}$ There is no guarantee, however, that this will continue to be the case following Brexit and the release of the UK government from its EU obligations. This uncertainty gives rise to the following question: imagine the UK significantly downgrades in national planning policy the importance to be attributed to making reductions in nitrogen dioxide. Imagine, further, that a local planning authority grants permission for the development of a site which will result in a significant increase in the levels of nitrogen dioxide present in ambient air in the local area. Is there any room for the courts to impose a common law duty requiring the planning authority to explain in the clearest possible terms why it has seen fit to authorise the development? The answer to

\footnotetext{
${ }^{59}$ Directive 2008/50/EC of the European Parliament and of the Council of 21 May 2008 on ambient air quality and cleaner air for Europe.

${ }^{60}$ See especially $R$ (ClientEarth) $v$ Secretary of State for the Environment, Food \& Rural Affairs [2013] UKSC 25, [2015] 4 All ER 724; Case C-404/13 ClientEarth ECLI:EU:C:20142382; $R$ (ClientEarth) v Secretary of State for the Environment, Food \& Rural Affairs [2015] UKSC 28; ClientEarth (No 2) v Secretary of State for the Environment, Food and Rural Affairs [2016] EWHC 2740 (Admin). For my comment see Joanna Bell, 'ClientEarth (No 2): A Case of Three Legal Dimensions' (forthcoming in Journal of Environmental Law 2017). For the latest stage in the saga see https://transport-network.co.uk/Government-seeks-delay-for-air-quality-plan/14012 (last accessed 25 April 2017).

${ }^{61} \mathrm{NPPF}$ (n 12), [124].

${ }^{62}$ Air Quality Standards Regulations 2010 (SI 2010, 1001).
} 
this clearly turns, at least in part, on whether we see the duty to give reasons in this context as a mechanism for ensuring that central government planning policy is taken seriously or as a mechanism for protecting public interests to be regarded as fundamental of themselves.

34. There are, of course, no easy answers to these issues. On the one hand, a focus on the policy priorities of the government which happens to be in power at any one point can seem somewhat arbitrary: ought the extent to which local authorities are required to articulate clearly their reasons for inflicting damage on important public interests really be so vulnerable to political change? On the other, leaving the responsibility of identifying those aspects of the public interest which are deserving of special protection in the hands of judges is hardly entirely satisfactory: can we really expect judges to have a coherent and shared view on this matter? This article cannot hope to resolve these difficult issues. It would, however, be of considerable assistance if the Supreme Court in determining the Kent appeal, if it agrees with the general thrust of the Court of Appeal's approach, could give some consideration to them.

\section{Question 2: How Detailed Must Planning Authorities’ Reasons Be?}

35. A second question against which the Court of Appeal's reasoning in Kent and Oakley falls to be considered can be put as follows: say a local planning authority has resolved to grant planning permission, how does it know whether it is required to compile a special document detailing its reasons and, if so, how detailed that document must be?

36. The impact of the reasoning in Kent and Oakley, if upheld by the Supreme Court, would be to draw a distinction between broadly two categories of case. First, there are cases where the grant of planning permission infringes upon a protected public interest such as by authorising development within an Area of Outstanding Natural Beauty or on Green Belt Land. In such cases the local planning authority will be placed under a 'special onus of justification'63 requiring it to offer 'substantial reasons" ${ }^{64}$ for its decision approving planning permission in the face of such interests are spelled out in the clearest possible terms. This will not necessarily require the compilation of a special document. Where, for instance, a Planning Committee elects to implement the recommendations of a Planning Officer, and the officer's report is sufficiently clear, interested parties may be able to know with certainty the reasoning process which lead the committee to its decision. In other circumstances however, such as where a planning committee rejects the recommendations of an officer's report, there will be a need to attend specifically to the project of spelling out reasons. Kent is a neat illustration of this. Here the Court of Appeal required the local planning authority to draft a comprehensive statement of its reasons and to explain in clear terms its precise points of disagreement with the Planning Officer.

\footnotetext{
${ }^{63}$ Oakley (n 1), [78].

${ }^{64} \operatorname{Kent}(\mathrm{n} 1)$, [21].
} 
37. Second, however, are 'ordinary' cases in which no protected public interest is at stake. Here, no common law duty to give reasons arises. Of course, in the course of determining a planning application the authority's reasons will be disclosed to an extent. The Planning Officer's report will have to be published, as will the minutes of the Planning Committee meeting in which planning permission is granted. This, however, will be the extent of the planning authority's legal duties. A good example of such a case is Hawksworth. ${ }^{65}$ Here the applicant's argument that Peterborough $\mathrm{CC}$ was dutybound to offer specific reasons for its decision to grant permission to develop a shopping centre was rejected; the only obligations which bound the local planning authority were to publish the Planning Officer's Report and the minutes of the Planning Committee's meeting, both of which it had done.

38. Following the Court of Appeal's logic through to its natural conclusion, it would seem to be the case that this reasoning applies equally in cases where the planning authority departs from, as well as where the authority implements, the recommendation of the planning officer. That is, taken collectively the courts' reasoning strongly suggests that a local authority in an ordinary case may elect to depart from the conclusions of a planning officer without providing a specific statement of reasons. At first sight, this may appear unsatisfactory - the reasons disclosed in the minutes of planning committee meetings are often vague and brief - can it really be the case that a planning committee may depart from the reasoned report of an officer while providing only cursory reasons for doing so? The answer embedded in the Court of Appeal's reasoning, however, is as follows: it is not open to the judiciary, for the three reasons discussed above, to seek to create at common law a general duty to ensure that detailed reasons for grants of planning permission are clear and accessible; such a move would be contrary to the existing case law, would risk imposing a considerable administrative burden on local planning authorities in circumstances where the court is particularly ill-placed to assess the full extent of that burden and would encroach unduly into the sphere of the political actors which have recently removed a statutory duty of reason-giving in this sphere. The better approach, rather, is to begin from the position that there is generally no common law duty to give reasons for grants of planning permission and to recognise that this starting point can be displaced when there is a particularly acute interest is at stake.

39. In sum, then, the upshot of Kent and Oakley is to draw a distinction between two broad categories of case. First, the protected public interest case in which the local planning authority is placed under a 'special onus of justification' ${ }^{\prime 66}$ requiring it to offer 'substantial reasons ${ }^{967}$ for the decision to permit the development of land in the face of a strong public interest. Second, the 'ordinary' case in which the planning authority's duties of reason-giving are limited to the publication of the planning officer's report and the minutes of the committee's meeting. All of this seems to provide relatively clear guidance to public authorities. Where uncertainty is injected into this legal picture, of course, is in relation to where the line between the two categories of case is drawn. As noted above, there is an important ambiguity across the Court

\footnotetext{
${ }^{65}$ Hawksworth (n 48).

${ }^{66}$ Oakley (n 1), [78].

${ }^{67} \operatorname{Kent}(\mathrm{n} 1),[21]$.
} 
of Appeal's reasoning in Kent and Oakley on the subject of how one tells whether a particular public interest triggers the special 'onus of justification. ${ }^{68}$ It is to be hoped that the Supreme Court, if it agrees with the general thrust of the Court of Appeal's approach, will offer clearer guidance on this issue. However, in the meantime, what is clear is that looking to central government planning policy will be a helpful starting point. If policy clearly indicates that a particular public interest is to be accorded very substantial weight the Court of Appeal's reasoning suggests a common law duty to give clear reasons will arise.

\section{Question 3: When are Administrative Decision-Makers More Broadly Under a Common Law Duty to Give Reasons?}

40. The final question against which Kent and Oakley fall to be considered is wider than the previous two in that it concerns the common law duty to give reasons, not in the planning context only but, more broadly. The central question arising here can be put as follows: what does the Court of Appeal's reasoning in these cases suggest about the circumstances in which an administrative decision-maker will be placed under a common law duty to give reasons? In addressing this question, it is helpful to begin by taking a step back from Kent and Oakley and to think about how the common law duty has tended to be conceived by judges and scholars.

\section{The Common Law Duty to Give Reasons as a Mechanism for Protecting Individual Dignity}

41. Two points about the background to Kent and Oakley are particularly pertinent. The first is that there has been a clear tendency in the case law, and certain strands of the academic literature, to substantially ground the common law duty to give reasons in a normative concern to protect individual dignity. That is, to explain it as a duty the core function of which is to ensure that individuals who are required to bear a significant burden, or who are denied an important benefit, are treated in the process as an autonomous and rational agent deserving of respect as such. Take, for instance, the following passage written by Trevor Allan:

Giving reasons expresses respect just as a refusal or failure to do so... expresses contempt. As Lucas explains the point, a requirement to give reasons 'recognizes a party's right to be disappointed by an adverse decision, and the need to assuage it.' A principal purpose of the rules of natural justice, more generally, is to enable a person to identify with the decision-making process: by observing them we make it easier for him to accept the result and 'make it manifest to anyone disappointed at the outcome that we were solicitous of his interests. ${ }^{69}$

42. The clear idea underlying this passage is that the common law duty to give reasons serves primarily a dignitarian function. It does so by ensuring that, where a public authority determines that an individual ought to be subject to a substantial burden or denied an important

\footnotetext{
${ }^{68}$ Oakley (n 1), [80].

${ }^{69}$ Trevor Allan, 'Procedural Fairness and the Duty of Respect' (1998) 18 OJLS 497 citing John Lucas, On Justice (OUP 1980), 79-80.
} 
benefit, that individual is able to understand the reasons for which that decision has been made. Allowing her so to understand is thought to be a necessary part of treating her as a rational person and not as an object.

43. This line of reasoning played an important role, for example, in the classic House of Lords judgment in $R v$ Secretary of State for the Home Department, ex parte Doody [1994] 1 AC 531 (HL). In this case, Lord Mustill, speaking with the unanimous approval of their Lordships, concluded that the Home Secretary, in setting the minimum tariff of imprisonment to be served by prisoners convicted of murder, was under a common law duty to give reasons for the decision. The main reason for this clearly invoked the dignitarian grounds articulated by Allan in the passage above:

Is the refusal to give reasons fair? I would answer without hesitation that it is not... [The prisoner] never sees the Home Secretary; he has no dialogue with him: he cannot fathom how his mind is working. There is no true tariff, or at least no tariff exposed to public view which might give the prisoner the idea of what to expect. The announcement of his first review date arrives out of thin air, wholly without explanation. The distant oracle has spoken and that is that. ${ }^{70}$

44. This tendency to ground the common law duty to give reasons in dignitarian concerns has had important practical consequences. It has meant, in particular, that the duty has tended to be confined to a particular kind of case, namely, cases where a particularised decision is being taken about how some individual ought to be treated and where that decision will have a substantial impact on that individual's interests. Here the dignitarian argument can be quite naturally invoked in order to make the argument that the individual ought, as a matter of fair treatment, to be given the opportunity to understand the reasons for which the decision has been made. The classic cases in which the common law duty to give reasons has been recognised all fit this fact pattern. Thus, as explained above, Doody ${ }^{71}$ concerned a decision to decision to set the minimum tariff to be served by an individual prisoner. Similarly, $R v$ Civil Service Appeal Board, ex parte Cunningham [1991] 4 All ER 310 (CA) concerned a decision to fix the amount of criminal injuries compensation to be paid to an individual applicant at an amount considerably lower than that which could usually be expected. Finally, the decision challenged in $R v$ Ministry of Defence, ex parte Murray [1998] COD 134 (DC) was to sentence an individual soldier to imprisonment on the basis of wounding offences. ${ }^{72}$

45. The extent of the courts' tendency to confine the common law duty to give reasons to such particularised decisions is well illustrated by $R$ (Hasan) $v$ Secretary of State for Trade and

\footnotetext{
${ }^{70} R$ v Secretary of State for the Home Department, ex parte Doody [1994] 1 AC 531 (HL), 564-565.

${ }^{71}$ Ibid.

${ }^{72}$ See also $R v$ City of London Corporation, ex parte Matson [1997] 1 WLR 765; $R v$ University of Cambridge, ex parte Evans [1998] ELR 515 (QB), Adami v Ethical Officer [2005] EWCA Civ 1754, [2007] LLR 1; R (Lee-Hirons) $v$ Secretary of State for Justice [2016] UKSC 46, [2017] AC 52.
} 
Industry [2008] EWCA Civ $1312 .{ }^{73}$ In this case the applicant, 'a Palestinian living in a village near Bethlehem ${ }^{74}$ sought to argue that the Secretary of State for Trade \& Industry was under a common law duty, wherever it opted to grant a licence to export military equipment to one of 20 'Major Countries of Concern' 75 to publish the details of that decision. The Court of Appeal regarded this argument as suffering from 'serious conceptual difficulties. ${ }^{, 76}$ The reason why the court was of this view is clearly expressed in the following passage:

There is no authority which comes close to supporting a public law duty of the kind and width required for this amended claim to succeed. There are of course many instances where a public authority is obliged to give reasons for decisions which affect individuals... Administrative decisions affecting individuals often require reasons to be given so that the individual may know why the decision has been made, and so that he may exercise rights of review... [The case law on the subject] concern[s] a duty to give reasons to and for the benefit of a person or persons affected. ${ }^{77}$

46. The common law duty to give reasons, in other words, has traditionally been grounded in a concern to protect the dignity of individuals about whom important decisions are being taken. This rationale had no application in Hasan and the Court of Appeal took this fact to be conclusive of the issue in the case.

\section{The Common Law Duty to Give Reasons as a Mechanism for Promoting Good Administration}

47. The second point which ought to be noted by way of background before returning to Kent and Oakley is that certain commentators have long been urging the courts to uproot the common law duty to give reasons from its traditional dignitarian groundings and substantially ground it in a very different and more public-facing set of normative concerns. The basic idea is well illustrated by the following passage from an article written by Michael Fordham QC in 1998: ${ }^{78}$

The giving of reasons serves the interests of the decision-making in reaching the decision... The central point is simple. Consciously duty-bound to articulate their reasons, decisionmakers' mind are the more focused and their substantive decision-making the better. ${ }^{79}$

48. In a similar way, Mark Elliott has argued as follows:

If administrative decisions are routinely accompanied by reasons - and if those reasons, for the most part, demonstrate that decisions are taken carefully and conscientiously - this

\footnotetext{
${ }^{73} R$ (Hasan) $v$ Secretary of State for Trade and Industry [2008] EWCA Civ 1312, Official Transcript.

${ }^{74}$ Ibid, [3].

${ }^{75}$ Ibid, [4].

${ }^{76}$ Ibid, [5].

${ }^{77}$ Ibid, [7] (my emphasis).

${ }^{78}$ Michael Fordham, 'Reasons: The Third Dimension' (1998) 3 JR 58.

${ }^{79}$ Ibid, [1].
} 
is likely to enhance the confidence of the wider public in the administrative system, and thus its willingness to cooperate with that system... Requiring reasons to be given may serve as a form of discipline upon decision-makers: knowledge that reasons will eventually have to be produced may "concentrate the decision-maker's mind on the right questions" and encourage an appropriately careful and thorough approach to the decision-making process. ${ }^{80}$

49. The argument can be put as follows: regardless of the impact a decision has on any one individual, there are generally strong normative reasons for imposing a duty to give reasons. Such a duty would promote transparency. It would lead to higher quality decision-making as decision-makers, aware of the need to explicitly offer reasons for their decisions, would ensure that they turn their minds to all of the relevant dimensions of the issue and think through them conscientiously. It would also serve to promote public trust by increasing awareness on the part of citizens of the rigour of the reasoning processes which inform public authority decisionmaking. As such, the courts ought to recognise a general common law duty to give reasons. This duty would arise in all cases, except where the public authority is able to point to a clear public interest which points against disclosure of reasons.

50. The courts to date have consistently declined the invitation to reconceptualise the common law duty to give reasons in this way. Hasan, ${ }^{81}$ as well as Kent and Oakley themselves, are clear illustrations of this. There seem to be broadly three main, closely related, reasons for the courts' hesitance in this regard.

51. Firstly, the courts are generally far more comfortable with intervening to protect individualised values, such as dignity, than more public-facing values such as transparency and good administration. This may stem from a concern that, while the courts are well-placed to make an assessment of the full impact of a decision on an affected individual, they are less well positioned to be able to assess the impact of a legal change on the general quality of administrative decision-making. It might be argued, for example, that the effect of introducing a general duty to give reasons would be to decrease the quality of administration. This might be the case for a number of reasons. Perhaps, for example, it would necessitate the deviation of scarce resources to the task of reason-giving and introduce an unwelcome element of delay into the system. Perhaps, furthermore, it would foster an environment in which administrative decision-makers simply offer systematic, 'judge-proof' reasons for their decisions contributing little, if anything, to public trust. ${ }^{82}$ The extent to which these arguments are convincing is, of

\footnotetext{
${ }^{80}$ Mark Elliott, 'Has the Common Law Duty to Give Reasons Come of Age Yet?' [2011] PL 56, 62 (citing $R$ v Higher Education Funding Council, ex parte Dental Surgery [1994] 1 WLR 242, 256).

${ }^{81}$ Hasan (n 73).

${ }^{82}$ See for example Jerry Mashaw, 'Public Reason and Administrative Legitimacy' in John Bell, Mark Elliott, Jason Varuhas \& Philip Murray (eds), Public Law Adjudication in Common Law Systems: Process and Substance (Hart 2016).
} 
course, difficult to assess ${ }^{83}$ and there is a clear sense in which the courts feel ill-equipped to make the necessary assessments for themselves.

52. This first reason for hesitance is bolstered by a second. The courts are especially reluctant to embrace a general duty to give reasons on the broad ground of promotion of good administration in light of the Freedom of Information Act. ${ }^{84}$ This piece of legislation arguably reflects a sustained attempt by Parliament to think through the question of the extent to which transparency would optimally enhance administrative decision-making. The fact that Parliament opted not to implement a general duty to give reasons but favoured a more limited scheme has been said to 'militate against the incremental judicial perception of a common law duty to [disclose information] to the same or any wider extent. ${ }^{, 85}$

53. Thirdly, it is also clear that an array of practical questions would arise from recognition of a general common law duty to give reasons to which there are no straightforward answers. Would recognition of such a duty mean, for example, that public authorities are duty-bound in relation to every decision they reach to publish their reasons for deciding thus? Surely this cannot be right. Such a conclusion would have serious implications for privacy in cases like Doody and Cunningham in which a particularised decision is taken about one individual. The proper conclusion in such cases is surely that the relevant individual is entitled to be given the reasons for the decision if she so requests. But how is the line to be drawn between cases where it is necessary to make reasons publicly available and cases where it is necessary to make reasons available on request? And who is to be regarded as entitled to have a request for reasons answered in any particular cases? Ambiguities such as these have surely been one reason for which the courts have favoured an incremental approach to the development of the duty to give reasons.

\section{Kent and Oakley: A Middle Way?}

54. To summarise, then, the common law duty to give reasons has traditionally been grounded in a normative concern to protect individual dignity with the consequence that it has tended to be confined to cases of particularised decision-making where something important to the individual is at stake. Commentators have long been urging the courts to reconceptualise the duty in more public-facing concerns such as transparency and good administration with the result that the duty would apply generally. The courts, however, continue to resist this rather dramatic change in thinking.

55. The significance of Kent and Oakley against this broader background is as follows. The Court of Appeal in these cases is beginning to carve out a middle way position. According to it, there are a number of normative triggers for the common law duty to give reasons. One is individual

\footnotetext{
${ }^{83}$ For challenges to them see for example Elliott (n 80); Justice-All Souls Committee, Administrative Justice: Some Necessary Reforms (Oxford 1998).

${ }^{84}$ Freedom of Information Act 2000.

${ }^{85}$ Hasan (n 73), [18].
} 
dignity. Thus where a particularised decision has been taken to impose a substantial burden on, or deny an important benefit to, an individual the decision-maker may be placed under a duty to explain clearly the reasons for the decision. There are, however, fundamental public interests other than individual dignity which may trigger the duty. Thus, in both Kent and Oakley the fact that a decision was taken to inflict substantial harm on a protected or important aspect of the environment was thought to justify imposing a high standard of reason-giving than would ordinarily apply. As noted above, there are different ways of thinking on the subject of what it is about certain public interests which justifies the imposition of this special 'onus of justification. ${ }^{86}$ According to one way of thinking, it is that the relevant interest has acquired through policy and law a special status which makes it appropriate to demand the clearest of justifications in those cases where a public authority chooses to inflict harm on it. According to another, it is that there are certain public interests, regarded as fundamental of themselves, in relation to which the courts see fit to impose special legal protections.

\section{Conclusion: The Supreme Court's Choice}

56. By way of conclusion it seems helpful to offer a brief summary of the main options open to the Supreme Court in determining the upcoming Kent appeal. Three main options in particular emerge from the discussion in this article. First, the Supreme Court could opt to uphold the general thrust of the Court of Appeal's reasoning. This would involve embracing the idea that local planning authorities are under a duty to offer 'substantial reasons ${ }^{, 87}$ for granting planning permission in circumstances where the relevant development will result in the doing of significant harm to a protected public interest. If the Supreme Court settles on this this option, it is to be hoped that it will give careful consideration to the question of what it is about certain environmental interests which trigger this duty in relation to which, as explained above, the Court of Appeal's reasoning contains an important ambiguity.

57. Second, the Supreme Court could decide that the common law duty to give reasons has applicability in relation of the grant of planning permission than the Court of Appeal suggests. The court might, for instance, determine that a duty to give reasons arises only when statute imposes such a duty, ${ }^{88}$ or where the grant of planning permission would have a substantial impact on the interests of an individual such that the dignitarian argument has force. The problem with this approach, however, is that it would erect an absolute divide between fundamental interests of an individual and of a public nature. It is difficult to see why, for instance, the duty to give reasons might arise where a decision substantially impacts the interests of one person but not where the grant of planning permission will result in the doing of irreversible harm to land, such as Areas of Outstanding Natural Beauty and Green Belt land, in which we arguably all have a legitimate interest, especially where central government has seen fit to mark out that interest as being deserving of special weight.

\footnotetext{
${ }^{86}$ Oakley (n 1), [80].

${ }^{87} \operatorname{Kent}$ (n 1) [21].

${ }^{88}$ For example, EIA Regulations (n 19), regulation 24.
} 
58. Third, the Supreme Court could determine that the common law duty to give reasons has a greater role in relation to grants of planning permission than is recognised by the Court of Appeal, most obviously by embracing the applicant's 'wide' argument in Oakley. Such an approach, however, risks imposing significant administrative burdens, which the courts are not well placed to assess, on planning authorities. There is also an important question to be addressed as to whether imposition of a general duty to give reasons is justifiable in a context in which the political branches have recently legislated to remove a statutory duty to a similar effect. 